\title{
DERIVING CRITICAL LOADS FOR ASIA
}

\author{
JEAN-PAUL HETTELINGH ${ }^{1}$, HARALD SVERDRUP ${ }^{2}$, DIANWU ZHAO ${ }^{3}$
}

\author{
${ }^{1}$ Nat. Inst. for Public Health and the Environment (RIVM), P.O.Box 1, NL-3720 BA Bilthoven, The Netherlands \\ ${ }^{2}$ Department of Chemical Engineering II, Lund University, P.O Box 124, S-22100 Lund, Sweden \\ ${ }^{3}$ Research Center for Eco-Environmental Sciences, P.OBox 2871, 100085 Beijing, China
}

\begin{abstract}
Critical loads have been computed and mapped in Southeast Asia, comprising China, Korea, Japan, The Philippines, Indo-China, Indonesia and the Indian subcontinent. The methodology involved the Steady-State Mass Balance (SSMB) method, originally developed for Europe. In contrast to Europe, where critical loads were computed for forest soils and surface waters, in Asia critical loads for 31 different vegetation types have been computed. Critical chemical limits as well as soil stability criteria were derived for each of these vegetation types, which include both natural and managed ecosystems. Results show that low critical loads in Asia occur in BanglaDesh, Indo-China, Indonesia and the southern part of China. Uncertainties of the results are mainly due to uncertainties in base cation deposition. The critical loads are part of the impact module of the Asian version of the Regional Air pollution INformation and Simulation model (RAINS-Asia), a model used to assess abatement strategies for sulfur emissions which are rapidly increasing in this part of the world. The difference in the level of detail between European and Asian critical load maps enables different applications. In Europe, critical loads for sulphur were used in comparison to actual sulphur deposition with the aim of decreasing the excess of sulphur deposition over critical loads through optimal emission abatement. In Asia in general and China in particular the geographical distribution of critical loads of sensitive ecosystems, with some emphasis on crops, is likely to be used as a basis for future emission (re-)allocation.
\end{abstract}

Key words: acid deposition, air pollution impacts, critical loads, integrated modeling, ecosystem sensitivity.

\section{Introduction}

Due to high economic growth, emissions of $\mathrm{SO}_{2}$ in Asia are rapidly increasing from about $34 \mathrm{Mt}$ in 1990 to about $110 \mathrm{Mt}$ by 2020 when no control measures are taken (Foell et al., 1995). Historical data in Europe provide evidence of the relationship between soil and surface water acidification and increasing emissions, transport and deposition of sulfate. Therefore, it is appropriate to investigate the risk of damage due to acidification in Asia (see also Rodhe and Herrera, 1988; Zhao and Xiong, 1988; Zongwei and Kyunfeng, 1991; Xue and Schnoor, 1994). A Regional Air pollution, INformation and Simulation model for Asia (RAINS-Asia) has been developed to assess the relationship between the energy system, sulfur emissions, long-range dispersion and environmental impacts. The impact module of RAINS-Asia (Hettelingh et al., 1995a) is used to provide information on the probability of damage from acid deposition exceeding critical loads for emission reduction alternatives (Foell et al., 1995). The critical load concept has been used in negotiations of the reduction of sulfur emissions in Europe (Hettelingh et al., 1995b) with the aim of decreasing the excess of sulfur deposition over critical loads through cost-optimal emission abatement. The derivation of critical loads in Asia, which is described in this paper, was improved in comparison to the European application, e.g. by including significantly more vegetation types. This improved resolution may also enable the use of critical loads as a basis for future emission (re-)allocation. 


\section{Computation and Mapping of Critical Loads in Asia}

Critical loads were computed for Asian ecosystems by means of the Steady-State Mass Balance (SSMB) method. This method was applied in conjunction with the semiquantitative method of relative sensitivity (Kuylenstierna and Chadwick, 1989) in order to compare the areas with stock-at-risk. The application of the method of relative sensitivity to Asia is described elsewhere (Cinderby et al., 1995). This paper focusses on the quantitative assessment of critical loads in Asia using the SSMB method.

\subsection{THE STEADY-STATE MASS BALANCE METHOD}

The SSMB method is extensively described elsewhere (Downing et al., 1993; Sverdrup and de Vries, 1994). In Europe critical loads were computed with the SSMB method mainly for forest soils and surface waters. For Asia an improvement to the European exercise was made by including 31 ecosystems in the critical load assessment. The computation of critical loads is based on plant response criteria and soil stability criteria. A critical molar ratio of the concentrations of base cations to aluminum in soil solution, $(B C / A l)_{c r i t}$, for each plant species is used as indicator of plant response. Using these critical $\mathrm{BC} / \mathrm{Al}$ ratios in the SSMB method it is possible to compute maximum allowable acidifying deposition, i.e. the critical load:

$$
C L=A N C_{w}+\left(1.5 \frac{x_{C a+M g+K} A N C_{w}+B C_{d}-B C_{u}}{\left(B C / A l_{c r i t} K_{g t b b}\right.}\right)^{1 / 3} Q^{2 / 3}+1.5 \frac{x_{C a+M g+K} A N C_{w}+B C_{d}-B C_{u}}{\left(B C / A D_{c r i t}\right.}
$$

where $A N C_{w}$ is the alkalinity produced by weathering, $A N C_{l, c r i t}$ is the critical alkalinity leaching, $K_{g i b b}$ the gibbsite solubility constant, $Q$ is the runoff, $B C_{d}$ the base cation deposition, $B C_{u}$ the base cation uptake and $x_{C a+M g+K}$ the fraction of weathering as $\mathrm{Ca}, \mathrm{Mg}$ and $\mathrm{K}$. The soil stability criterion is introduced to avoid that acid deposition leads to $\mathrm{Al}$ leaching in excess of $\mathrm{Al}$ produced by weathering and other processes, e.g. in high precipitation areas. The critical load for acidity based on the soil stability criterion is computed by:

$$
C L=3 A N C_{w}+\left(2 \frac{A N C_{w}}{K_{g t b b}}\right)^{1 / 3} Q^{2 / 3}
$$

Critical loads for each ecosystem are computed by taking the minimum of equations (1) and (2).

\subsection{DATA AND MAPPING}

Several different types of response expressions, using the $\mathrm{BC} / \mathrm{Al}$ ratio as explanatory variable, can be derived from assuming an antagonism between base cations and Al through different types of ion exchange at the roots. The response equation can be made specific for (a) particular species, and (b) a particular ion exchange mechanism, i.e. Vanselow, Gapon or Gaines-Thomas (Sverdrup and Warfvinge, 1993). An example of relationships 
between root growth reduction and $\mathrm{BC} / \mathrm{Al}$ ratios in soil solution is given in Fig.1 for five tree species. Critical values for $\mathrm{BC} / \mathrm{Al}$ as thresholds for root growth reduction have been established for many plant species by Sverdrup and Warfvinge (1993). An overview of the ecosystems for which critical loads have been computed is provided in Table 1.

Other data, i.e. climate, soil, geology and vegetation data, and their geographical distribution, required to compute and map critical loads have been derived from a variety of sources which are summarized in Cinderby et al. (1995). The uncertainty of the critical load estimates is largely due to the uncertainties of base cation weathering and base cation deposition estimates which require further verification.

In order to be able to compare sulfur depositions, which are computed by the RAINSAsia model on a raster of $1^{\circ} \times 1^{\circ}$ grid cells, with critical loads the original polygon map of critical load has to be converted to the same raster. Each grid cell contains several critical loads reflecting the variety of ecosystems and their areas. A cumulative distribution of these critical loads is derived for each grid cell allowing the computation of a $p$ th percentile (protecting 100- $p$ percent of the ecosystem area) for comparison with the deposition in that grid cell (see Hettelingh et al., 1995a).

TABLE 1

Values used for the calculation of critical loads with the SSMB method in Asia (see Hettelingh et al., 1995a; some vegetation types of a total of 31 have been lumped for convenience).

\begin{tabular}{lllll}
\hline Vegetation type & $(B C / A l)_{\text {crit }}$ & Root depth $(\mathrm{m})$ & $\log _{10} K_{\text {gibb }}$ & $B C_{u}\left(\mathrm{eq} \mathrm{h}^{-1} \mathrm{y}^{-1} \mathrm{I}^{1}\right)$ \\
\hline Polar or rock desert & 6 & 0.1 & 8.1 & 0 \\
Tundra & 2 & 0.2 & 8.1 & 0 \\
Cool semi-desert/ scrub & 2 & 0.3 & 8.1 & 0 \\
Montane cool scrub/grass & 2 & 0.3 & 8.1 & 0 \\
Cool scrub/grassland & 2 & 0.3 & 8.1 & 0 \\
Main + southern taiga & 1 & 0.5 & 8.5 & 250 \\
Coniferous forest & 1.5 & 0.5 & 8.5 & 250 \\
Mixed forest & 1 & 0.8 & 8.5 & 250 \\
Temperate broadleaf forest & 0.6 & 0.8 & 8.5 & 250 \\
Interrupted temperate woods & 1 & 0.5 & 8.5 & 100 \\
Dry/highland woods & 2 & 0.5 & 8.5 & 100 \\
Mediterranean woodland & 1 & 0.5 & 8.5 & 100 \\
Interrupted tropical woods & 2 & 0.5 & 8.1 & 0 \\
Subtropical dry forest & 2 & 0.5 & 8.5 & 100 \\
Subtropical wet forest & 1 & 0.2 & 8.1 & 0 \\
Tropical dry forest & 1 & 0.5 & 8.5 & 100 \\
Tropical wet forest & 0.6 & 0.2 & 8.1 & 0 \\
Tropical savanna & 10 & 0.5 & 8.5 & 100 \\
General farmland & 10 & 0.3 & 8.3 & 0 \\
Coastal wetland & 10 & 0.5 & 8.5 & 0 \\
Hot scrub/grassland & 10 & 0.3 & 8.3 & 50 \\
Succulents/thorn dry woods & 10 & 0.3 & 8.3 & 50 \\
Semi-arid forest & 10 & 0.5 & 8.3 & 50 \\
Non-polar rocky vegetation & 10 & 0.2 & 8.5 & 0 \\
Sand and semi desert & 10 & 0.5 & & 0 \\
& & & & \\
\hline
\end{tabular}




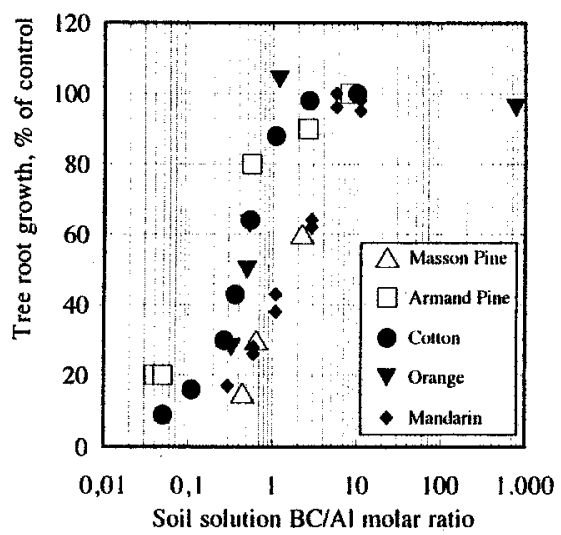

Fig.1.The relationship between root growth reduction and $\mathrm{BC} / \mathrm{Al}$ ratios for five tree species growing in China. For example, a root growth reduction of less than $20 \%$ occurs for $B C / A l>1$ (Sverdrup and Warfvinge, 1993).

\section{Results}

Fig.2 shows the map of critical loads for acidity in Asia. Low critical loads (i.e. below 500 eq $\mathrm{ha}^{-1} \mathrm{yr}^{-1}$ ) are found in south-eastern Asia, parts of the Himalayan range and the Tibetan plateau and in parts of the boreal forest in northern China. Other areas with low critical loads (high sensitivity) include the rain forest strip in south-western India.

These results do not imply that soils are acidified yet. Fig. 2 illustrates that some areas with low critical loads are subject to a higher risk of acidification than other areas. The map provides indications of where continued excess of critical loads may, in some areas earlier than in others, ultimately exhaust the buffering capacity of the soils. Areas with an increased risk of growth reduction, yield loss or dieback can thus be located. The dry regions in most of India and north-western China show relatively high critical loads (exceeding $2000 \mathrm{eq} \mathrm{ha}^{-1} \mathrm{yr}^{-1}$ ). The 25 th percentile critical load, i.e. protecting $75 \%$ of the ecosystems in each grid cell against sulfur based acidification has been chosen as basis for comparison with sulfur deposition. The reason of choosing the 25 th percentile is that the resolution of the vegetation data, used as basic map in the SSMB method, does not allow reliable estimates of ecosystem protection when lower percentiles are chosen. Fig.3 shows the 25 th percentile critical load map of acidity for every $1^{\circ} \times 1^{\circ}$ grid cell covering Asia.

\section{Concluding Remarks}

A first critical load map for Asia has been derived by applying the Steady-State Mass Balance method to 31 vegetation types, taking into account information on soil types and climatic and meteorological conditions which are specific to the Asian region. The map of critical loads presented in this paper (a) enables large scale assessments of areas at risk due to long-range dispersion of acidifying pollutants, and (b) may assist in decisions on emission (re-)allocations. However, the calculation of critical loads for much of Asia with its highly varying environmental conditions and ecosystems is a considerable effort. 


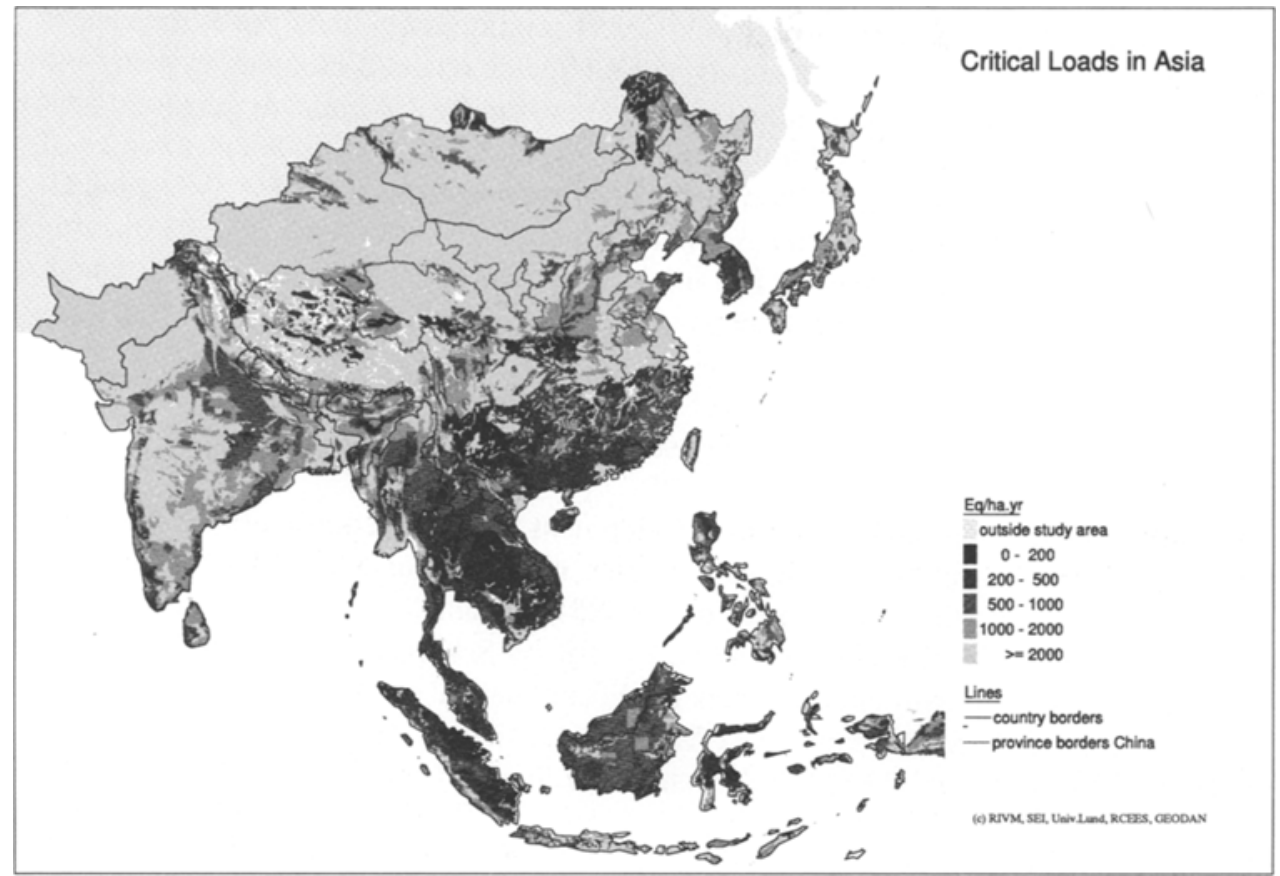

Fig.2. Critical loads in Asia computed with the Steady-State Mass Balance Method.

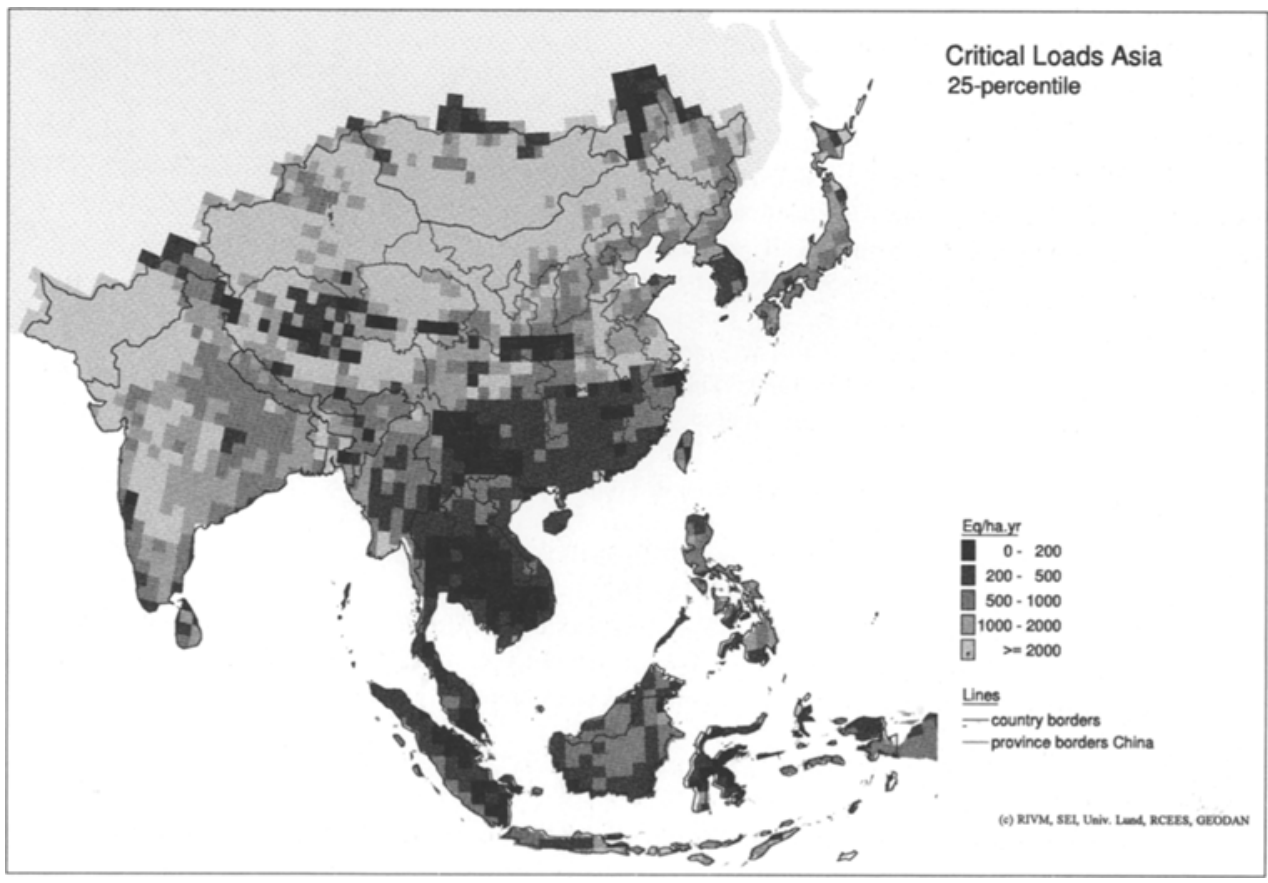

Fig.3. The 25-percentile critical load, protecting $75 \%$ of the ecosystems in each $1^{\circ} \times 1^{\circ}$ grid cell in Asia. 
They encompasses tropical rain forest to near desert conditions and mangroves to areas of taiga: there is an associated range of soil types and a wide range of cropping systems and land use. Therefore, extensive validation procedures are required to improve the assessment of risk of damage on local scales. Further work is also required to include other causes of risk of damage in addition to deposition. Atmospheric concentrations of $\mathrm{SO}_{2}, \mathrm{NO}_{\mathrm{x}}$, and $\mathrm{O}_{3}$ have been shown to cause direct damage to natural ecosystems and crops, as well as having health effects in large urban areas. In fact in many parts of Asia the concern for urban air quality is increasing and air concentrations of $\mathrm{SO}_{2}$ may already reach hazardous levels.

\section{Acknowledgements}

The World Bank (J.Shah) and the Asian Development Bank (A.Azimi) are acknowledged for supporting the project "Acid rain and emission reductions in Asia". Our colleagues in the scientific team for the development of RAINS-Asia are M.Amann, R.L.Arndt, G.R. Carmichael, J.Cofala, W.K.Foell, C.Green, L.Hordijk, W.Schöpp and D.Streets. The design of the impact module in particular has benefited from the collaboration with M.Chadwick, J.Kuylenstierna and S.Cinderby (SEI-York), J.U.Ahmad (Bangla-Desh), T.X.Gian (Vietnam), S.Lee (Korea), C.M.Liu (Taiwan) and J.Shindo (Japan).

\section{References}

Cinderby, S., Kuylenstierna, J.C.I. and Chadwick, M.J.: 1995, "Background Data and Mapping the Sensitivity in Asia", In: Hettelingh et al., op. cit. pp. 27-42.

Downing, R.J., Hettelingh, J.-P. and de Smet, P.A.M.: 1993, "Calculation and Mapping of Critical Loads in Europe", CCE Status Report 1993, RIVM, Bilthoven, The Netherlands, 163 pp.

Foell, W.K., Green, C., Amann, M., Bhattacharya, S., Carmichael, G., Chadwick, M., Cinderby, S., Haugland, T., Hettelingh, J.-P., Hordijk, L., Kuylenstierna, J., Shah, J., Shresta, R., Streets, D. and Zhao, D.: 1995, "Energy Use, Emissions, and Air Pollution Reduction Strategies in Asia", this volume.

Hettelingh, J.-P., Chadwick, M., Sverdrup, H., and Zhao, D.: 1995a, "Assessment of Environmental Effects of Acidic Deposition", RIVM, Bilthoven, Netherlands, 145 pp.

Hettelingh, J.-P., Posch, M., de Smet, P.A.M., Downing, R.J.: 1995b, "The Use of Critical Loads in Emission Reduction Agreements in Europe", this volume.

Kuylenstiema, J.C.I. and Chadwick, M.J.: 1989, "The Relative Sensitivity of Ecosystems in Europe to the Indirect Effects of Acidic Depositions", In: Kämäri et al. (Eds), Regional Acidification Models, Springer, Heidelberg, $306 \mathrm{pp}$.

Rodhe, H. and Herrera, R. (Eds): 1988, "Acidification in Tropical Countries", SCOPE 36, John Wiley, Chichester, 405 pp.

Sverdrup, H. and de Vries, W.: 1994, "Calculating Critivcal Loads for acidity with the Simple Mass Balance Method", Water, Air, and Soil Pollution, 72, 143-162.

Sverdrup, H. and Warfvinge, P.: 1993, "Effect of Soil Acidification on Growth of Trees and Plants as Expressed by the $(C a+M g+K) / A l$ Ratio", Report 2:1993, Department of Chem. Eng. II, Lund University, Lund, Sweden.

Xue, H.B. and Schnoor, J.L.: 1994, "Acid Deposition and Lake Chemistry in Southwest China", Water, Air, and Soil Pollution, 75, 61-78.

Zhao, D. and Xiong, J.: 1988, "Acidification in Southwestern China", In: H. Rodhe and R. Herrera (Eds), op. cit., pp. 317-347.

Zongwei, F. and Kyunfeng, S.: 1991, "Relative Sensitivities of Woody Plants to Acid Deposition in South Areas of China", Journal of Environmental Sciences (China), 3(2), 61-68. 